\title{
Growth of weaner steers grazing Tagasaste (Chamaecytisus palmensis) over summer/autumn with and without cereal grain supplements
}

\author{
GD Tudor ${ }^{1}$, W Standing 2, ND Costa ${ }^{3}$, JB Rowe ${ }^{4}$

\begin{abstract}
1Dept of Agriculture Western Australia, PO Box 1231, Bunbury, 6230; 2Dept of Agriculture Western Australia, Baron-Hay Court, South Perth, 6151; ${ }^{3}$ School of Veterinary Science, Murdoch University, Murdoch, 6150; ${ }_{4}^{4}$ Animal Science Dept, University of New England, Armidale, NSW, 2350, Australia
\end{abstract}

Tagasaste (Chamaecytisus palmensis), from the barren volcanic hills in the Canary islands, is a hardy, perennial leguminous shrub reaching 3 to $5 \mathrm{~m}$ in height with very leafy stems and branches. It grows well in the medium rainfall zone $(\sim 450 \mathrm{~mm})$ in the southwest region of Western Australia where there are an estimated 700,000 ha of leached deep sands. The variation in the protein (14- $25 \%)$ and energy (65-80\% in vitro dry matter digestibility) of tagasaste through the year suggests high rates of growth in cattle should be possible. Growth rates $>1.3 \mathrm{~kg} / \mathrm{d}$ have been recorded in spring but growth in autumn is poor. Cereal grain supplements in autumn could complement the protein of the green leafy material to produce a well balanced production diet.

One hundred and four weaner cross-bred steers were stratified on initial liveweight of $238 \pm 28.4 \mathrm{~kg} \mathrm{(} \pm \mathrm{SD})$ and allocated at random into 3 treatments each with 3 replicates : control ( $n=31$; no supplements), low grain ( $n=34$; supplement fed at $0.75 \%$ of liveweight) and high grain ( $n=39 ; 1.5 \%$ of liveweight). The animals grazed the tagasaste and were supplemented for 120 days. Different stocking pressure was used to equalise availability of energy from tagasaste and grain supplements, between treatments. Cereal barley grain (11.0 MJ ME/kg DM and $9.3 \%$ crude protein) was cracked and mixed with virginiamycin $®$ (SmithKline Beecham Animal Health) at $40 \mathrm{~g} / \mathrm{t}$ to control acidosis (Rowe and Zorrilla-Rios, 1993, Rec Adv Anim Nutr Aust, 89-96.). The animals were weighed every 2 weeks and supplemented animals were fed weekly. At the end of the experiment 30 animals ( 10 from each treatment) were bled by jugular puncture and plasma was analysed for metabolic profile including plasma urea and creatinine. The data were analysed by ANOVA.

The average ME and crude protein of the tagasaste was $9.4 \mathrm{MJ} / \mathrm{kg} \mathrm{DM}$ and $13.7 \%$, respectively. Animals with no grain supplement only maintained weight and the increase in liveweight gain in the grain supplemented animals reflected grain consumption. The barley supplement substituted for, and did not stimulate tagasaste intake. Plasma urea and creatinine levels suggest the lack of growth is due to a protein deficiency caused by inability of the animals to utilise the protein from the tagasaste. This may be due to the phenolic and flavinol compounds which increase in concentration in summer and autumn, and have been shown to decrease fermentation of protein in the rumen (Waghorn, 1990, Proc Aust Soc Anim Prod, $18,412-415)$.

\begin{tabular}{lccc}
\hline Treatments & Control & Low Grain & High Grain \\
Growth rate $(\mathrm{kg} / \mathrm{d})$ & $-0.07^{\mathrm{a}}$ & $0.16^{\mathrm{b}}$ & $0.46^{\mathrm{c}}$ \\
Final liveweight $(\mathrm{kg})$ & $254^{\mathrm{a}}$ & $265^{\mathrm{b}}$ & $297^{\mathrm{c}}$ \\
Plasma urea $(\mathrm{mM})$ & $4.5^{\mathrm{a}}$ & $2.1^{\mathrm{b}}$ & $3.4^{\mathrm{c}}$ \\
Creatinine $(\mu \mathrm{M})$ & $213.3^{\mathrm{a}}$ & $170.0^{\mathrm{b}}$ & $173.1^{\mathrm{b}}$ \\
Grain intake $(\mathrm{kg} / \mathrm{d})$ & 0 & 1.9 & 3.7 \\
ME maintenance and growth $(\mathrm{MJ} / \mathrm{d})$ & 32 & 38 & 48 \\
ME from grain $(\mathrm{MJ} / \mathrm{d})$ & 0 & 19 & 36 \\
ME from tagasaste $(\mathrm{MJ} / \mathrm{d})$ & 32 & 19 & 12 \\
Est. intake tagasaste $(\mathrm{kg} / \mathrm{d})$ & 3.4 & 2.0 & 1.3 \\
\hline
\end{tabular}

Means in the same row with different superscripts are significantly different at $P<0.01$. 